\title{
Study the ICT-Based Tutorial Model for Upper-Class of Elementary School in the Perspective of Constructivist Approach
}

\section{Telaah Model Tutorial Berbasis TIK Kelas Atas Sekolah Dasar dalam Perspektif Pendekatan Konstruktivistik}

\author{
Uswatun Chasanah ${ }^{1}$, Andi Prastowo ${ }^{2}$ \\ 1,2Universitas Islam Negeri Sunan Kalijaga Yogyakarta, Indonesia \\ 120204081015@student.uin-suka.ac.id, 2 andi.prastowo@uin-suka.ac.id
}

\section{DOI: 10.18860/mad.v13i2.11297}

Abstract. This research aims to reveal the syntax, factors that take effect the application process of the ICT-based tutorial model, and the strengths of the tutorial model from a constructivist approach to online learning. The research method used in this research is the library research method with a descriptive qualitative approach. The research subjects were online learning articles and tutorial models. The data analysis technique was carried out by analyzing the contents of the document, namely precious research scientific articles and relevant theories. The results in this study point out that the tutorial model can be one of the solutions and means to be utilized during the online learning process SD/MI. the tutorial model was developed by combining the software in a coherent and tested manner. Variations of tutorial models are tailored to the needs and characteristics of students. The syntax of the ICT-based tutorial model includes an introduction, presentation of information, question and responses, judging of responses, providing about responses, remediation, sequencing lesson segment, and closing. The ability of teachers and students, as well as the existence of devices, laptops, and internet networks, are supporting factors. Meanwhile, the quality of the internet network connection speed is an inhibiting factor. The tutorial model can facilitate students to be more independent when learning, evaluate self-achievement, flexible, and learner-centred. However, the tutorial model can trigger boredom, frustration due to frequent remedies, depending on teacher directions, and limited free applications. The tutorial model is in tune with the perspective of a constructivist approach. The ICTbased tutorial model can help teachers carry out online learning according to process standards, provide meaningful experiences for students, effective, and efficient experiences for students.

Keywords. Tutorial Model; ICT; Constructivistic

Abstrak. Tujuan dari penelitian ini adalah untuk mengungkapkan sintaks, faktor yang berpengaruh pada proses penerapan model tutorial berbasis TIK, dan kelebihankelemahan model tutorial dalam sudut pandang pendekatan konstruktivistivistik pada pembelajaran daring. Penelitian ini menggunakan metode library research dengan pendekatan kualitatif deskriptif. Subjek penelitian adalah artikel pembelajaran daring dan model tutorial. Teknik analisis data dilaksanakan dengan cara menganalisis isi dokumen, yakni artikel ilmiah penelitian sebelumnya dan teori yang relevan. Hasil dalam penelitian ini menunjukkan bahwa model tutorial dapat menjadi salah satu solusi dan sarana untuk dimanfaatkan selama proses pembelajaran daring SD/MI. Model tutorial dikembangkan dengan mengkombinasikan pada software secara runtut dan teruji. Variasi model tutorial disesuaikan dengan kebutuhan dan karakteristik

Vol. 13 No. 2 Juni 2021

Madrasah homepage: http://ejournal.uin-malang.ac.id/index.php/Madrasah/index 


\section{MADRASAH}

Jurnal Pendidikan dan Pembelajaran Dasar

p ISSN: 1979-5599 | e ISSN: 2502-194X

peserta didik. sintaks model tutorial berbasisi TIK antara lain pendahuluan, penyajian materi, pertanyaan dan jawaban, penilaian, memberikan respon, pengulangan, segmen pengaturan pelajaran, dan penutup. Kemampuan guru dan peserta didik, serta adanya gawai, laptop, dan jaringan internet menjadi faktor pendukung. Sementara kualitas kecepatan koneksi jaringan internet merupakan faktor penghambat. Model tutorial mampu memfasilitasi peserta didik lebih mandiri ketika belajar, mengevaluasi pencapaian diri sendiri, fleksibel, dan terpusat pada peserta didik. namun model tutorial dapat memicu terbitnya rasa bosan, frustasi karena sering remidi, bergantung pada arahan guru, dan terbatasnya aplikasi yang tidak berbayar. Model tutorial seirama dengan perspektif pendekatan konstruktivistik. Model tutorial berbasis TIK dapat membantu guru melaksanakan pembelajaran daring sesuai dengan standar proses, memberikan pengalaman berkesan untuk peserta didik, efektif, dan efisien.

Kata Kunci. Model Tutorial; TIK; Pendekatan Konstruktivistik

Received: 08-01-2021

Approved: 27-04-2021

Revised: 24-04-2021

Published: 01-05-2021

Copyright (C) Madrasah Jurnal Pendidikan dan Pembelajaran Dasar. All Right Reserved. This is an open access article under the CC BY-SA license

(Creative Commons Attribution-ShareAlike 4.0 International License.).

Correspondence Address: 20204081015@student.uin-suka.ac.id

\section{A. PENDAHULUAN}

Sejak adanya pandemi Covid-19 Menteri Pendidikan dan Kebudayaan memutuskan pembelajaran daring sebagai alternatif yang paling aman untuk melindungi peserta didik dari serangan virus Covid-19 (Menteri Pendidikan dan Kebudayaan Republik Indonesia, 2020). Selama proses pembelajaran daring tidak luput dari kendala atau permasalahan baik berdasarkan pengemasan materi pembelajaran, fasilitas, dan komunikasi atau hubungan antara guru, peserta didik, dan orang tua. Misalnya, peserta didik cepat merasa bosan selama pelaksanaan pembelajaran daring, dan pendampingan orang tua kepada peserta didik sewaktu proses pembelajaran daring yang kurang maksimal (Anugrahana, 2020, pp. 286-287). Selain peserta didik, guru juga mengalami kendala dalam pemanfaatan teknologi pada proses pembelajaran daring. Hanya $10 \%$ sampai $15 \%$ dari 2,7 guru di Indonesia yang memanfaatkan teknologi pada proses pembelajaran (Rahim et al., 2019, p. 134). Hal ini disebabkan oleh terbatasnya sarana dan prasana yang dapat mendukung pemanfaatan teknologi, belum semua daerah sudah terjangkau jaringan internet dan sinyal, belum semua daerah sudah terpasang saluran listrik, minimnya pengetahuan guru tentang teknologi secara teknis, dan waktu merencanakan pembelajaran berbasis teknologi terbatas (Bastudin, 2020). Dalam hasil penelitian Ningsih, dkk juga diungkapkan kendala yang sering dialami guru adalah persiapan menggunakan teknologi dalam pembelajaran menguras waktu, sekolah belum memiliki infokus yang cukup untuk semua kelas, tidak semua peserta didik memahami isi materi yang disampaikan, hal ini bisa disebabkan oleh keseimbangan antara isi materi, gambar, dan animasi. Selanjutnya, belum ada jaringan internet di sekolah dan layar infokus (Ningsih et al., 2020, pp. 522-523). Namun

Vol. 13 No. 2 Juni 2021

Madrasah homepage: http://ejournal.uin-malang.ac.id/index.php/Madrasah/index 
demikian, Iwan Syahril (Direktur Jenderal Guru dan Tenaga Kependidikan (Dirjen GTK) Kemendikbud) berkeyakinan pandemi Covid-19 membawa hikmah dalam dunia pendidikan. Guru semakin mengerti tentang teknologi dan menurunnya tingkat ketakutan menggunakan atau memanfaatkan teknologi dalam pembelajaran. Oleh sebab itu poin tersebut dapat membentuk terobosan dan harapan baru bagi pendidikan di Indonesia (Adit, 2020).

Pembelajaran daring termasuk pembelajaran yang memusatkan kepada peserta didik, dan menuntut peserta didik supaya mampu belajar secara mandiri (Sadikin \& Hamidah, 2020, p. 219). Hal ini sesuai dengan salah satu pendekatan pembelajaran yang digadang-gadang dapat melatih keterampilan peserta didik pada abad 21, yakni pendekatan konstruktivistik. Dimana proses pelaksanaan pembelajaran sudah berpusat kepada peserta didik, adanya kerjasama dengan kelompok, serta diintegrasikan dengan permasalahan dalam kehidupan sehari-hari (Mayasari et al., 2016, p. 51). Pelaksanaan kegiatan pembelajaran daring dapat dilakukan melalui pemanfaatan digital learning atau LMS sesuai dengan kemampuan setiap sekolah, seperti Google Classroom, rumah belajar, zoom atau video conference, live chat, telepon, maupun media perantara yang lainnya (Dewi, 2020, p. 58). Proses pelaksanaan pembelajaran daring dapat diintegrasikan dengan model-model pembelajaran berbasis TIK, seperti model drill and practice, model tutorial, model simulasi, games, dan model yang lainnya. Dalam penelitian ini peneliti akan mengkaji dan menelaah model tutorial, dimana model tutorial berorientasi mendesain pembelajaran berbentuk bimbingan kepada peserta didik secara individual, dan ini sangat sesuai dengan kondisi pembelajaran daring di era sekarang. Seperti pendapat Aripin, pemilihan model pembelajaran berbasis TIK disesuaikan dengan kebutuhan dan tujuan pembelajaran dalam suatu pembelajaran melalui media atau alat yang digunakan (Aripin, 2018, p. 4).

Sebelumnya Rafianti, dkk telah mengembangkan bahan ajar interaktif dengan memanfaatkan model tutorial pada materi sistem pertidaksamaan linier satu variabel untuk siswa SMP (Rafianti et al., 2018, p. 123). Yaswinda, dkk mengembangan media pembelajaran berbentuk video tutorial dalam pembelajaran sains berbasis multisensori ekologi yang dapat memberikan peningkatan terhadap kemampuan kognitif peserta didik taman kanan-kanak kelompok A (Yaswinda et al., 2019, p. 107). Video pembelajaran berbasis tutorial yang dirancang menggunakan software autoplay media studio 7.0 efektif dalam meningkatkan pemahaman mahasiswa pada mata kuliah teknik perawatan dan perbaikan alat telekomunikasi, hal ini dibuktikan dengan meningkatnya hasil tes para mahasiswa (Hanafi, 2017, p. 56). Tidak hanya itu, prestasi belajar peserta didik kelas XII IPS-1 mata pelajaran TIK meningkat setelah memanfaatkan video pembelajaran berbasis tutorial (Sumantri, 2019, p. 58). Penelitian yang lain juga menyebutkan sebesar $66,7 \%$ dan $69,4 \%$ peserta didik sangat senang belajar IPA menggunakan komputer model tutorial, sebesar 27,8\% dan 27,8\% peserta didik senang belajar IPA dengan menggunakan komputer model tutorial, dan sebesar 5,6\% dan 2,8\% peserta didik kurang senang belajar IPA dengan menggunakan komputer model tutorial (Sutarman, 2016, p. 90). Peserta didik lebih mudah memahami materi jika kegiatan pembelajaran dikemas dalam bentuk video, infografis, online meeting, serta games (Angga, 2020, p. 96).

Hasil pada pemaparan di atas sebagai bukti dari tujuan pemanfaatan pembelajaran berbasis TIK model tutorial, yaitu untuk memudahkan peserta didik ketika belajar dan memahami materi yang dipelajari secara menyeluruh (Rusman, 2018,

Vol. 13 No. 2 Juni 2021

Madrasah homepage: http://ejournal.uin-malang.ac.id/index.php/Madrasah/index 


\section{MADRASAH}

Jurnal Pendidikan dan Pembelajaran Dasar

p ISSN: 1979-5599 | e ISSN: 2502-194X

p. 214). Model tutorial memiliki beberapa fungsi, diantaranya; pertama, kurikuler (model tutorial dapat dijadikan sebagai perantara guru dalam menjelaskan materi); kedua, pembelajaran (model tutorial dapat memfasilitasi peserta didik supaya dapat belajar mandiri); ketiga, diagnosis-bimbingan (membantu peserta didik memecahkan masalah dan mengatasi permasalahan dalam pembelajaran); keempat, administratif (mencatat, melaporkan, memberikan nilai, maupun secara teknik administrasi lainnya sesuai dengan peraturan program CBI); kelima, personal (secara tidak langsung model tutorial dapat menjadi teladan yang baik kepada peserta didik, misalnya cara belajar, menyusun materi, cara bersikap dan berperilaku positif, memberikan motivasi belajar mandiri dan meningkatkan prestasi) (Rusman, 2018, p. 213). Kreativitas dan inovasi dalam memanfaatkan pembelajaran digital atau multimedia dengan model tutorial dapat menjadi solusi dan perantara selama proses pembelajaran daring di era pandemi covid-19.

Berdasarkan uraian di atas, pertanyaan penelitian yang dibahas di sini adalah bagaimana sintaks, faktor-faktor yang berpengaruh pada proses penerapan model tutorial berbasis TIK, dan kelebihan-kelemahan model tutorial dalam sudut pandang pendekatan konstruktivistivistik pada pembelajaran daring untuk jenjang SD/MI di kelas atas.

\section{B. METODE PENELITIAN}

Penelitian ini menggunakan metode studi pustaka (Arifin, 2014, pp. 54-55). Subjek dalam penelitian ini adalah artikel-artikel penelitian dengan topik model tutorial dalam pembelajaran daring dan atau pembelajaran berbasis TIK. Sumber data penelitian ini berupa lima buah artikel dan lima buah buku referensi. Teknik pengumpulan data dilakukan dengan dokumentasi, yakni dengan cara melakukan identifikasi baik dalam artikel, jurnal, buku, maupun informasi lain yang sejalur dengan arah permasalahan yang sedang diteliti. Sementara teknik analisis data, dilakukan dengan cara melakukan analisis wacana atau menganalisis isi dari dokumendokumen yang sudah terkumpul dan tersusun dengan sistematis. Setelah dianalisis baik perbandingan atau penguatan, maka dapat ditarik benang merah sebagai kesimpulan jawaban dari permasalahan yang sedang dikaji.

\section{HASIL DAN PEMBAHASAN}

\section{Hasil Penelitian}

Pelaksanaan Pembelajaran harus disesuaikan dengan karakteristik perkembangan peserta didik, sesuai dengan rentang usianya dan diarahkan dalam satuan yang holistik (Menteri Pendidikan dan Kebudayaan Republik Indonesia, 2016). Guru harus mampu mengemas kegiatan pembelajaran menjadi menarik, bermakna bagi peserta didik, dan saling berhubungan dengan aktivitas atau kegiatan peserta didik dalam kehidupan sehari-hari (Susanto, 2019, p. 109). Layaknya prinsip utama pembelajaran daring, yaitu terciptanya interaksi antara satu peserta didik dengan peserta didik yang lain, guru dengan peserta didik, dan peserta didik dengan lingkungan sekitar supaya terciptanya kegiatan pembelajaran yang kondusif dan sederhana (A.N et al., 2019, p. 36). Sebab usia sekolah dasar memasuki usia sekitar 7-11 tahun, dimana peserta didik lebih mudah mengidentifikasi dan menganalisis apa yang

Vol. 13 No. 2 Juni 2021

Madrasah homepage: http://ejournal.uin-malang.ac.id/index.php/Madrasah/index 
berada jelas dan tepat di depan mata daripada mengidentifikasi dan menganalisis sesuatu yang masih bersifat abstrak (Prastowo, 2019, p. 100).

Walaupun pembelajaran dilakukan secara daring, tidak menutup kemungkinan pembelajaran tetap harus disajikan secara bermakna dan menarik bagi peserta didik. Seirama dengan penjelasan dalam Handbook yang dieditori oleh Lory W. Anderson dan David R. Krathwohl, pembelajaran dikatakan bermakna jika terdapat transfer rangkaian pengetahuan empiris yang memicu kreativitas siswa dalam menyelesaikan masalah, yakni diberikan topik, memecahkan masalah dan mencari solusi, kemudian menyampaikan hasilnya kepada teman-temannya (L. W. Anderson \& Krathwohl, 2017, p. 97). Salah satu kendala yang sering dialami guru selama pembelajaran daring adalah ketika mengemas materi pembelajaran. Dalam proses pengemasan materi guru harus melakukan dengan teliti dan hati-hati, harus sesuai dengan KI dan KD supaya tidak terjadi miskonsepsi antara guru dengan murid atau orang tua (Rigianti, 2020, p. 300).

Untuk mengatasi permasalahan tersebut, guru dapat mengemas materi pembelajaran melalui pembelajaran berbasis TIK model tutorial, model tutorial ini dinilai lebih efektif dan efisien untuk dijadikan sebagai panduan atau media perantara menyampaikan dan menjelaskan materi (Sukardi \& Rozi, 2019, p. 99). Model tutorial adalah satu diantara model pembelajaran berbasis TIK yang sudah terbukti dapat membuat kemampuan otak kanan dan otak kiri peserta didik menjadi seimbang dan menaikkan kemampuan kecerdasan visual peserta didik sehingga lebih mudah memahami pesan yang disampaikan melalui pengamatan (Darmawan, 2009, p. 336). Hal ini didukung dengan hasil penelitian Evaliata $\mathrm{Br}$ Sembiring dkk, hasil tuntas peserta didik meningkat 50\%, dari 33,3\% menjadi 83,3\% (Sembiring et al., 2018, p. 111). Penelitian Annisa Al Karimah dkk hasil skor keefektifan 4,23 (Al Karimah et al., 2017, p. 12).

Pemanfaatan model tutorial dalam pembelajaran berbasis TIK selain dapat dikembangkan dengan menggunakan software Lectora Inpire (Fasthea \& Tim Penyusun, 2014, p. 7), juga dapat mengembangkan video pembelajaran berbasis tutorial kemudian diunggah di Youtube maupun dikirimkan di Whatsapp Group (WAG), memanfaatkan aplikasi Augmented Reality (AR), maupun aplikasi software lainnya seperti Adobe Flash, Macromedia Flash MX dan Macromedia Director MX, dan software yang lain (Rusman, 2018, p. 224). Sesuai dengan penjelasan Sharon E. Smaldino, Deborah L. Lowther, dan James D. Russel proses pelaksanaan model tutorial meliputi dari instruktur kepada peserta didik, dari peserta didik kepada peserta didik, dari komputer ke peserta didik, dan dari cetakan kepada peserta didik (Smaldino et al., 2014, p. 35). Selain guru dituntut untuk menguasai teknologi yang akan digunakan, pemilihan media tersebut juga harus disesuaikan dengan karakteristik peserta didik.

Seperti yang sudah dilakukan para peneliti sebelumnya ketika mengembangkan produk atau media pembelajaran dengan memanfaatkan model tutorial, diantaranya; pembelajaran melalui video pembelajaran berbasis tutorial, Siswa hanya perlu mengunduh video yang sudah dibagikan guru melalui Whatsapp Group (WAG) maupun Google Classroom. Jika sudah diunduh siswa dapat memutar video pembelajaran dengan mode offline dan mempercepat atau memperlambat video (Batubara \& Batubara, 2015, p. 82). Selain video berbasis tutorial, model tutorial juga dapat digunakan untuk mengembangkan software tes berbasis komputer yang bisa dimanfaatkan para guru (Admaja et al., 2019, pp. 65-66). Perlu diketahui, 90\% hasil belajar peserta didik dipengaruhi indera pandang, 5\% dipengaruhi indera dengar, dan 5\% dipemgaruhi

Vol. 13 No. 2 Juni 2021

Madrasah homepage: http://ejournal.uin-malang.ac.id/index.php/Madrasah/index 


\section{MADRASAH}

Jurnal Pendidikan dan Pembelajaran Dasar

indera lainnya (Rusman, 2018, p. 219). Seperti hasil komparasi dari penelitian sebelumnya, skor rata-rata dari hasil belajar peserta didik adalah sebesar 66,9 (Desfiyani et al., 2014, p. 45).

Contoh lain implementasi pembelajaran berbasis TIK model tutorial adalah dengan menggunakan teknologi Augmented Reality (AR), seperti sebuah aplikasi media pembelajaran "Jelajah Angkasa AR" pada materi tata surya. Media pembelajaran ini merupakan aplikasi android yang merubah gambar pada kartu marker berubah menjadi animasi 3D (Setyawan et al., 2019, p. 83). Penjelasan tersebut dikuatkan oleh hasil penelitian sebelumnya, yakni sebesar $87,5 \%$ peserta didik lebih mudah memahami materi tata surya setelah memanfaatkan multimedia interaktif (Melinda et al., 2018, p. 44). Hasil tersebut membuktikan kebenaran prinsip-prinsip multimedia dalam pembelajaran daring, dimana peserta didik lebih mudah mencerna penjelasan dari gambar atau grafik dengan kata-kata dalam satu waktu dan disajikan dengan dekat dalam halaman atau layar (T. Anderson, 2008, p. 172).

\section{Pembahasan}

\section{a. Sintaks Model Tutorial}

Pembelajaran berbasis TIK model tutorial memberikan pengaruh yang signifikan dalam proses pembelajaran. Mengembangkan model tutorial harus disusun secara sistematis dan teruji supaya memperoleh hasil yang lebih baik dan tujuan kompetensi dapat tercapai dengan maksimal (Sukardi \& Rozi, 2019, pp. 99-100). Secara teoritis sintaks pengembangan pembelajaran berbasis TIK model tutorial dapat digambarkan pada bagan berikut (Darmawan, 2016, p. 15):

Gambar C.1 . Sintaks Pengembangan Pembelajaran Berbasis TIK Model Tutorial

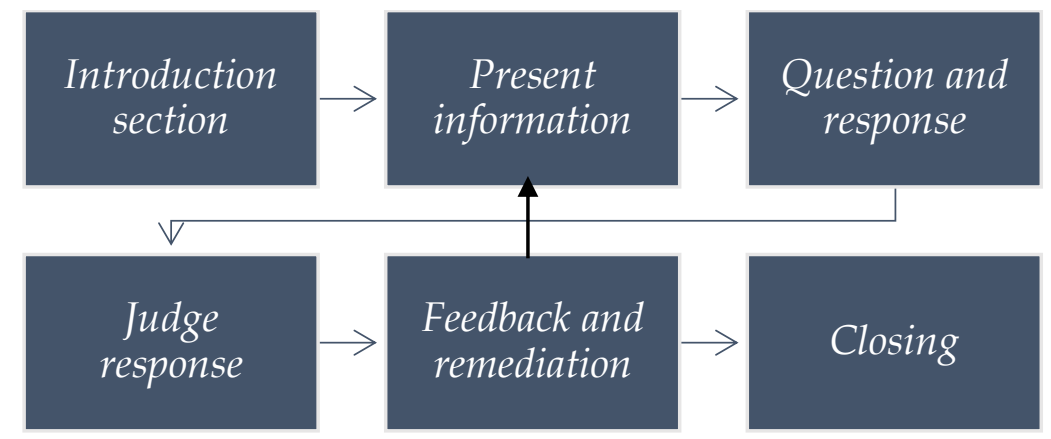

Dalam sebuah artikel hasil penelitian sebelumnya mengungkapkan ada delapan langkah, secara berurutan yaitu Pendahuluan (introduction), penyajian informasi (presentation of information), pertanyaan dan jawaban (question of responses), penilaian respon (judging of responses), pemberian balikan respons (providing feedback about responses), pengulangan (remediation), segmen pengaturan pelajaran (sequencing lesson segment), penutup (closing) (Noverdika, 2021, p. 111). Sementara menurut Kemendiknas (dalam bukunya Mariyaningsih) terdapat enam langkah dalam proses pembelajaran berbasis tutorial. Pertama, Penyajian informasi (presentation of information). Kedua, pertanyaan dan respon (question of responses). Ketiga, penilaian respon (judging of responses). Keempat, memberikan feedback (providing feedback about responses). Kelima, 
pengulangan (remediation). Keenam, segmen pengaturan pelajaran (sequencing lesson segment) (Mariyaningsih \& Hidayati, 2018, p. 78). Berdasarkan pemaparan di atas, peneliti menyimpulkan sintaks penerapan pembelajaran berbasis TIK model tutorial secara rinci adalah sebagai berikut: Pertama, pendahuluan (Introduction). Kedua, penyajian materi (Presentation of Information). Ketiga, pertanyaan dan jawaban (Question and Responses). Keempat, penilaian (Judging of Responses). Kelima, memberikan respon (Providing Feedback About Responses). Keenam, remidial (Remediation). Ketujuh, segmen pengaturan pelajaran (Sequencing Lesson Segmen). Kedelapan, penutup (Closing).

Tahapan yang pertama adalah introduction, yaitu menampilkan scene salam pembuka, petunjuk penggunaan, tombol pilihan menu, dan pengenalan media pembelajaran yang dikembangkan (Rusman, 2018, p. 223). Selain itu, dalam tahapan ini juga dapat menyajikan standar kompetensi atau kompetensi inti, kompetensi dasar, indikator, serta tujuan pembelajaran (Wardani et al., 2019, p. 24). Tahapan yang kedua adalah presentation of information. Senada dengan hasil penelitian Ervina Wahyuningsih dkk, tampilan materi harus sesuai dengan standar kompetensi atau kompetensi inti, kompetensi dasar, indikator, dan tujuan pembelajaran (Wahyuningsih \& Mustadi, 2016, p. 37). Namun demikian, dalam penyajian materi harus memperhatikan karakteristik bentuk penyajian materi, keseimbangan tampilan teks, grafik, animasi, konsistensi, jenis huruf dan warna yang digunakan sesuai karakteristik usia sekolah dasar (Rusman, 2018, pp. 281-283). Menurut Pett dan Wilson (dalam bukunya (Smaldino et al., 2014, p. 83)) Harmonisasi warna antara warna utama dengan warna pelengkap dapat menarik perhatian peserta didik, lebih fokus, dan dapat menciptakan emosi peserta didik. Smaldino, Lowther, dan Russel juga berpendapat umumnya usia sekolah dasar menyukai warna panas seperti merah, merah muda, kuning, jingga, maupun warna terang serta kombinasi dari warna yang lebih tua (Smaldino et al., 2014, p. 85).

Tahapan yang ketiga adalah question and responses, hasil penelitian sebelumnya mengatakan pertanyaan yang disajikan harus relevan dengan materi yang sedang dipelajari dan didesain dengan menarik (Kusuma et al., 2018, p. 195). Menurut Rusman, jika dalam satu segmen lebih dari satu materi, maka pertanyaan dapat diberikan setiap akhir materi (Rusman, 2018, pp. 225-227). Selain itu, selama pembelajaran daring guru dapat menampilkan bentuk soal HOTS dalam model tutorial berbasis TIK untuk menstimulus kemampuan berpikir tingkat tinggi kelas atas (Nugroho, 2019, p. 85). Misalnya untuk meningkatkan aspek C4, C5, dan C6 dengan memberikan studi kasus atau permasalahan disertai gambar atau bagan (Ichsan et al., 2019, p. 5). Penelitian sebelumnya mengungkapkan terjadinya peningkatan kemampuan kognitif setelah diberikan soal HOTS selama pembelajaran daring (Ramlee et al., 2019, p. 145).

Tahapan keempat adalah judge of responses, yaitu hasil penilaian ditampilkan secara langsung kepada peserta didik dengan memberikan tanggapan secara langsung berdasarkan hasil nilai dan jawaban peserta didik (Rusman, 2018, p. 284). Sistem penilaian dalam model tutorial berbasis TIK dapat menggunakan formative assessment dan summative assement. Jenis soal bersifat variatif, dapat berupa kuis dan tes, seperti multiple choice, pencocokan, dan penyelesaian (Sewell et al., 2010, pp. 300-302). Tahapan kelima adalah providing feedback about responses dan tahapan keenam remediation, Menurut Mariyaningsih dan Hidayati, tanggapan dapat diberikan ditengah dan diakhir mengerjakan soal, atau diakhir saja. Dan peserta didik yang belum mencapai KKM dapat diberikan perlakuan remedial atau penguatan untuk peserta didik yang nilaianya mencapai KKM (Mariyaningsih \& Hidayati, 2018, p. 78). Senada

Vol. 13 No. 2 Juni 2021

Madrasah homepage: http://ejournal.uin-malang.ac.id/index.php/Madrasah/index 


\section{MADRASAH}

Jurnal Pendidikan dan Pembelajaran Dasar

p ISSN: 1979-5599 | e ISSN: 2502-194X

P a g e

dengan hasil penelitian Zulkipli, adanya latihan soal tersebut dapat digunakan untuk mengukur pencapaian peserta didik setelah belajar dengan memanfaatkan pembelajaran berbasis TIK model tutorial disertai dengan feedback dari hasil kerja peserta didik (Zulkipli, 2015, p. 556). Providing about responses dan remediation mempunyai misi untuk memberikan infromasi benar atau salah jawaban yang diberikan pesera didik, disertai dengan adanya penguatan jika jawaban benar dan hukuman yang dapat memotivasi peserta didik jika jawaban salah. Hukuman tersebut dapat berupa mengulangi mengerjakan soal tersebut hingga jawaban benar (Uma, 2012, p. 26).

Tahapan ketujuh adalah sequencing lesson segmen, yakni dengan meneydiakan space untuk peserta didik supaya dapat dijadikan tempat untuk mengatur subbagian sesuai yang dibutuhkan oleh peserta didik (Mariyaningsih \& Hidayati, 2018, p. 78). Seperti disediakan menu-menu pilihan dan pengaturan pemberian nilai dan feedback secara otomatis, berupa shape atau tombol yang bisa diklik oleh peserta didik. Mulai dari pendahuluan, materi, pertanyaan, jawaban, penilaian, feedback, hingga penutup. Tujuannya supaya dapat memudahkan peserta didik dan memberikan ruang untuk peserta didik untuk mengeksplor sesuai kebutuhannya. Sebagaimana yang dijelaskan dalam bukunya Rusman, pola pembelajaran model tutorial menggunakan tipe branching, setiap materi atau mata pelajaran yang akan disampaikan ditampilkan dalam bentuk menu pilihan yang bercabang (Rusman, 2018a, p. 212). Dan tahapan kedelapan closing, yaitu menampilkan ringkasan materi, salam penutup, dan ucapan terima kasih (Rusman, 2018, p. 232). Ringkasan dapat berupa paragraf intisari dari materi sebelumnya yang sudah dipelajari. Selain itu, dalam penutup juga dapat disajikan informasi kepada peserta didik tentang materi yang akan dipelajari di bagian selanjutnya (Jaya et al., 2015, p. 40).

\section{b. Faktor yang Mempengaruhi Pelaksanaan Model Tutorial}

Kelancaran proses pembelajaran berbasis teknologi yang memanfaatkan model tutorial bergantung kepada kompetensi guru dan peserta didik dalam memanfaatkan teknologi. Apabila guru maupun peserta didik mahir dalam mengaplikasikan teknologi maka pembelajaran TIK berbasis model tutorial ini dapat berjalan dengan lancar, sebaliknya apabila guru dan peserta didik kurang mahir maka perlu adanya pelatihan menggunakan software tersebut terlebih dahulu (Munir, 2017, p. 24). Kelancaran pembelajaran daring juga ditentukan oleh ketersediaan laptop, gawai, dan jaringan internet yang stabil (Rigianti, 2020, p. 229). Dikarenakan sekarang pembelajaran dilaksanakan secara daring, maka bandwith koneksi internet provider yang digunakan dapat menjadi faktor penghambat berjalannya proses pembelajaran, jika bandwith koneksi internetnya lemah maka peserta didik maupun guru akan kesulitan untuk mengunduh atau mengunggah materi pembelajaran yang akan dipelajari. Menurut Data Pokok Pendidikan (Dapodik) terdapat 12 ribu sekolah yang belum mempunyai akses untuk menggunakan internet dan 48 ribu satuan pendidikan mempunyai koneksi internet yang buruk (CNN Indonesia, 2020).

Vol. 13 No. 2 Juni 2021

Madrasah homepage: http://ejournal.uin-malang.ac.id/index.php/Madrasah/index 


\section{c. Kelebihan dan Kelemahan Model Tutorial}

Model tutorial dapat dijadikan sebagai alternatif dalam menyajikan materi, baik berupa teks, gambar, grafik, audio, maupun animasi. Tidak jauh berbeda dengan model pembelajaran berbasis teknologi yang lainnya, pembelajaran berbasis teknologi informasi dan komunikasi model tutorial memiliki kelebihan dan kelemahan. Model diciptakan untuk melengkapi sarana atau sebagai alat untuk menyampaikan materi pembelajaran. Hasil penelitian terdahulu siswa menjadi lebih mandiri dalam membuat atau mengerjakan tugas dan guru merasa lebih mudah dalam menjelaskan materi kepada peserta didik setelah menggunakan media pembelajaran berbasis tutorial (Putra et al., 2013, p. 139). Menggunakan multimedia interaktif model tutorial selama pembelajaran terbukti efektif untuk meningkatkan motivasi dan hasil belajar peserta didik kelas atas MI (Sobarna \& Darmawan, 2014, p. 397). Peningkatan minat, motivasi, dan hasil belajar peserta didik setelah menggunakan media pembelajaran model tutorial tersebut disebabkan oleh design media pembelajaran tersebut sudah sesuai dengan karakterististik peserta didik, dengan kata lain media pembelajaran model tutorial tersebut mengandung teks, gambar, video, audio, dan animasi (Prayoga et al., 2016, p. 9).

Kelebihan model tutorial juga dapat diidentifikasi melalui fungsi model tutorial, yakni dapat memberikan fasilitas belajar mandiri kepada peserta didik, mampu menjadi perantara komunikasi dengan peserta didik, memfasilitasi peserta didik dalam memecahkan dan menyelesaikan problem dengan mandiri, dapat menampung proses rekapitulasi, pelaporan, penilaian, dan bentuk administrasi pembelajaran lainnya (Mariyaningsih \& Hidayati, 2018, pp. 77-78). Pendapat lain juga menguraikan kelebihan model tutorial, pertama, peserta didik dapat belajar atau mempelajari materi pembelajaran dengan mandiri; kedua, peserta didik dapat menelaah sendiri tingkat kemampuan mereka setelah mengerjakan soal; ketiga, peserta didik dapat melakukan evaluasi diri terhadap jawaban maupun hasil jawaban yang telah diinput (Smaldino et al., 2014, p. 35); keempat, dapat digunakan dimanapun berada dan dapat diulang tanpa ada batasan; kelima, dapat memberikan peningkatan terhadap pembelajaran student centered (Purwowidodo, 2018, p. 117).

Sementara kelemahan yang dimiliki model tutorial dalam pembelajaran berbasis teknologi informasi dan komunikasi adalah; pertama, model tutorial dapat membuat peserta didik merasa bosan jika materi yang disajikan hanya menggunakan satu arah; kedua, peserta didik dapat merasakan frustrasi jika hasil yang dicapai tidak memenuhi standar walaupun sudah melakukan remedial (pengulangan); ketiga, proses pembelajaran menjadi kurang efektif jika arahan dari guru dalam proses pembelajaran teknologi dengan menggunakan model tutorial ini kurang jelas dan sistematis; keempat, tidak semua aplikasi yang digunakan untuk mengembangkan pembelajaran berbasis teknologi model tutorial dapat diunduh secara gratis (Smaldino et al., 2014, p. 35). Penjelasan tersebut merupakan bukti pendukung dari hasil temuan Sobarna dan Darmawan, supaya peserta didik mampu menguasai konsep materi dan prinsip informasi yang disampaikan oleh guru, disertai dengan pencapaian sikap, pengetahuan, dan keterampilan. Maka, ketika menggunakan media pembelajaran model tutorial dalam pembelajaran harus disesuaikan dengan materi yang yang akan dipelajari oleh peserta didik (Sobarna \& Darmawan, 2014, pp. 395-396).

Vol. 13 No. 2 Juni 2021

Madrasah homepage: http://ejournal.uin-malang.ac.id/index.php/Madrasah/index 


\section{MADRASAH}

Jurnal Pendidikan dan Pembelajaran Dasar

p ISSN: 1979-5599 | e ISSN: 2502-194X

Bintoro Setyawan, Rufi'i, dan Noor Fatirul dalam jurnal penelitiannya yang berjudul "Augmented Reality dalam Pembelajaran IPA bagi Siswa SD" menjelaskan tujuan pengalaman belajar virtual bukan hanya untuk memperoleh pengetahuan, dengan demikian untuk mendapatkan full benefit dari pembelajaran dibutuhkan desain lingkungan pembelajaran dari pendekatan kosntruktivistik (Setyawan et al., 2019, p. 84). Pendekatan kosntruktivistik mengikrarkan pengalaman sebagai kunci utama untuk memperoleh pembelajaran bermakna, sehingga peserta didik dapat mengkonstruksi pengetahuan melalui pengalaman yang sudah diperoleh (Susanto, 2019, p. 112). Sebagaimana telah dibuktikan dalam penelitian Nyai Cintang dan Ari Meiza Nurkhasanah, pemahaman siswa terhadap konsep geometri meningkat sebesar 84,34\% setelah diterapkan pendekatan konstruktivisme selama proses pembelajaran (Cintang \& Nurkhasanah, 2017, p. 5).

Melalui pembelajaran dengan menggunakan model tutorial berbasis TIK mampu menstimulus kemampuan berfikir kreatif peserta didik. Karena dalam pembelajaran ini guru sebgai fasilitator dan motivator, sehingga peserta didik dapat berinteraksi dapat memperoleh pengalaman secara langsung dengan sumber belajar yang digunakan selama proses pembelajaran berlangsung (Lestari et al., 2020, p. 25). Penelitian yang lain juga mengungkapkan menggunakan model tutorial berbasis TIK selama pembelajaran dapat menumbuhkan karakter dan sikap positif hingga menimbulkan suasana pembelajaran yang kondusif, peserta didik mudah memahami materi, dapat mempelajari materi sampai tuntas, serta keaktifan peserta didik selama proses pembelajaran, seperti bertanya, menjawab, menanggapi, memperhatikan, membuat catatan, mengerjakan LKS, berdiskusi, dan presentasi (Haekal et al., 2014, pp. 61-63). Pemaparan tersebut selayaknya peran pendekatan konstruktivistik dalam membidani proses pembelajaran, yakni memberikan dorongan supaya peserta didik lebih mandiri dan pantang menyerah ketika memecahkan masalah, guru merangsang kreatifitas dan kekritisan peserta didik dengan memberikan pertanyaan, mengembangkan kemampuan berpikir tingkat tinggi peserta didik, melibatkan peserta didik secara langsung dan aktif selama proses kegiatan pembelajaran, seperti dialog, diskusi, dan memecahkan kasus (Husamah et al., 2018, pp. 101-102).

\section{KESIMPULAN}

Pembelajaran daring dengan model tutorial untuk jenjang SD/MI kelas atas dengan pendekatan konstruktivistik memiliki sintaks yang terdiri dari delapan tahapan, dimulai dari tahap pendahuluan, tahap penyajian informasi tahap pertanyaan dan jawaban, tahap penilaian respon, tahap pemberian balikan respons, tahap pengulangan, tahap segmen pengaturan pelajaran, dan diakhiri dengan tahap penutup. Temuan ini mirip dengan temuan sintaks model tutorial yang telah diungkapkan para penelitian sebelumnya. Sementara itu, keberhasilan penerapan pembelajaran daring dengan model tutorial ini dipengaruhi oleh dua faktor utama yaitu: kecakapan sumber daya manusia dalam pemanfaatan IT (pendidik dan peserta didik), ketersediaan perangkat dan infrastruktur internet yang memadai. Penelitian ini juga menemukan bahwa pembelajaran daring dengan model tutorial untuk jenjang SD/MI memiliki empat kelebihan yaitu: memfasilitasi siswa belajar secara mandiri (melatih problem solving, menelaah kemampuan diri dan evaluasi diri terhadap jawaban), meningkatkan

Vol. 13 No. 2 Juni 2021

Madrasah homepage: http://ejournal.uin-malang.ac.id/index.php/Madrasah/index 
pembelajaran berpusat pada siswa, lebih fleksibel digunakan di mana pun dan kapanpun, serta efisien dalam proses administrasi pembelajaran. Sedangkan kelemahannya adalah cenderung membuat siswa cepat bosan, menstimulasi frustasi siswa jika hasil tidak sesuai harapan, sangat membutuhkan kehadiran guru yang kompeten dalam memberikan arahan yang jelas dan sistematis, dan terkadang sulit diakses.

Penelitian ini diakui hanya berfokus pada studi pustaka maka temuan ini dimungkinkan bisa berbeda dalam konteks riil di lapangan. Oleh karena itu, temuan penelitian ini membuka peluang bagi peneliti berikutnya untuk melanjutkan penelitian dalam konteks riil di lapangan. Topik-topik terkait efektivitas pembelajaran daring dengan model tutorial di kelas atas dan kelas rendah, perbedaan efektivitas pembelajaran daring model tutorial di kelas atas dan kelas bawah, faktor-faktor yang memicu efektivitas dan efisiensi pembelajaran daring model tutorial di kelas, dan topiktopik lain yang sejenis bisa ditindaklanjuti dalam riset berikutnya.

\section{REFERENSI}

Adit, A. (2020). Dirjen GTK: Melek Teknologi adalah Hikmah Covid-19. https:/ / www.kompas.com/edu/read/2020/05/30/121709471/dirjen-gtkmelek-teknologi-adalah-hikmah-covid-19

Admaja, A. M., Kuswandi, D., \& Soepriyanto, Y. (2019). Pengembangan Multimedia Tutorial untuk Guru dalam Mengembangkan Software Tes Berbasis Komputer. JINOTEP (Jurnal Inovasi Dan Teknologi Pembelajaran): Kajian Dan Riset Dalam Teknologi Pembelajaran, 5(2), 63-68. https://doi.org/10.17977/um031v5i22019p063

Al Karimah, A., Rusdi, \& Fachruddin, M. (2017). Efektifitas Media Pembelajaran Matematika Menggunakan Software Animasi Berbasis Multimedia Interaktif Model Tutorial pada Materi Garis Dan Sudut untuk Siswa SMP/MTS Kelas VII. Jurnal Penelitian Pembelajaran Matematika Sekolah (JP2MS), 1(1).

A.N, S., Bayu, Rani, \& Suswandari, M. (2019). Persepsi Siswa dalam Studi Pengaruh Daring Learning Terhadap Minat Belajar IPA. Scaffolding: Jurnal Pendidikan Islam Dan Multikulturalisme, 1(2).

Anderson, L. W., \& Krathwohl, D. R. (2017). Kerangka Landasan untuk Pembelajaran, Pengajaran, dan Asesmen Diterj. Oleh Agung Prihantoro (Cet. Ke-2). Pustaka Pelajar.

Anderson, T. (2008). The Theory and Practice of Online Learning. Athabasca University Press.

Anugrahana, A. (2020). sHambatan, Solusi dan Harapan: Pembelajaran Daring Selama Masa Pandemi Covid-19 Oleh Guru Sekolah Dasar. Scholaria: Jurnal Pendidikan Dan Kebudayaan, 10(3), 282-289. https://doi.org/10.24246/j.js.2020.v10.i3.p282289

Arifin, Z. (2014). Penelitian Pendidikan Metode dan Paradigma Baru (Cet. Ke-3). Remaja Rosdakarya.

Aripin, I. (2018). Konsep dan Aplikasi Mobile Learning dalam Pembelajaran Biologi. Bio Educatio: (The Journal of Science and Biology Education), 3(1), Article 1. https:/ / doi.org/10.31949/be.v3i1.853 


\section{MADRASAH}

Jurnal Pendidikan dan Pembelajaran Dasar

p ISSN: 1979-5599 | e ISSN: 2502-194X

P a g e

Bastudin. (2020). Hambatan Utama Penggunaan Tik Dalam Pembelajaran Dan Strategi Mengatasinya. LPMP Sumatera Selatan. http://lpmpsumsel.kemdikbud.go.id/site/blog/2020/06/17/hambatan-utamapenggunaan-tik-dalam-pembelajaran-dan-strategi-mengatasinya/

Batubara, H. H., \& Batubara, D. S. (2015). Penggunaan Video Tutorial untuk Mendukung Pembelajaran Daring di Masa Pandemi Virus Corona. Muallimuna: Jurnal Madrasah Ibtidaiyah, Vol. 5 No. 2.

Cintang, N., \& Nurkhasanah, A. M. (2017). Peningkatan Pemahaman Konsep Bangun Datar Melalui Pendekatan Konstruktivisme Berbasis Teori Van Hiele. Educandum: Jurnal Pendidikan Dasar Dan Pembelajaran, Vol. 7(No. 1). http://ejournal.unipma.ac.id/index.php/PE/article/view/1144

CNN Indonesia. (2020). Kemendikbud: 12 Ribu Sekolah Tak Punya Akses Internet. https:/ / www.cnnindonesia.com/nasional/20201022123707-20-

561482/kemendikbud-12-ribu-sekolah-tak-punya-akses-internet

Darmawan, D. (2009). Komunikasi Pembelajaran: Berbasis Brain Information Communication and Technology. Humaniora.

Darmawan, D. (2016). Mobile Learning Sebuah Aplikasi Teknologi Pembelajaran. Rajawali Pers.

Desfiyani, A., Suyidno, S., \& Hartini, S. (2014). Komparasi Hasil Belajar Siswa Yang Menggunakan Pembelajaran Berbasis Komputer Model Drill dan Model Tutorial. Berkala Ilmiah Pendidikan Fisika, 2(1), 43. https:/ / doi.org/10.20527/bipf.v2i1.815

Dewi, W. A. F. (2020). Dampak COVID-19 terhadap Implementasi Pembelajaran Daring di Sekolah Dasar. Edukatif: Jurnal Ilmu Pendidikan, 2(1), 55-61. https:/ / doi.org/10.31004/edukatif.v2i1.89

Fasthea, S., \& Tim Penyusun. (2014). Merancang Desain Multimedia Pembelajaran Interaktif Menggunakan Software Lectora Inspire. Laboratorium Multimedia Pembelajaran Fakultas Ilmu Tarbiyah dan Keguruan UIN Sunan Kalijaga Yogyakarta.

Haekal, M. I., Suyatna, A., \& Viyanti. (2014). Pemanfaatan Media TIK Tutorial sebagai Subtitute Eksperimen Pembelajaran Alat Ukur SMP. Jurnal Pembelajaran Fisika, 2(2), Article 2. http:/ /jurnal.fkip.unila.ac.id/index.php/JPF/article/view/4356

Hanafi, H. (2017). Rancangan Multimedia Pembelajaran Berbasis Tutorial dengan Software Autoplay Media Studio 7.0. Jurnal TAM (Technology Acceptance Model), $8(1), 51-57$.

Husamah, Pantiwati, Y., Restian, A., \& Sumarsono, P. (2018). Belajar dan Pembelajaran (Cet. Ke-2). UMMPress.

Ichsan, I. Z., Sigit, D. V., Miarsyah, M., Ali, A., Arif, W. P., \& Prayitno, T. A. (2019). HOTS-AEP: Higher Order Thinking Skills from Elementary to Master Students in Environmental Learning. European Journal of Educational Research, 8(4), 935-942.

Jaya, H., Haryoko, S., \& Lu'mu. (2015). Praktikum Simulasi Berbasis Website. Edukasi Mitra Grafika.

Kusuma, R. D. F. D., Nasution, S. P., \& Anggoro, B. S. (2018). Multimedia Pembelajaran Matematika Interaktif Berbasis Komputer. Desimal: Jurnal Matematika, 1(2), 191199. https:// doi.org/10.24042/ djm.v1i2.2557

Lestari, A., Suryadi, A., \& Ismail, A. (2020). Pengaruh Media Pembelajaran Berbasis Komputer dengan Model Tutorial untuk Meningkatkan Hasil Belajar Siswa pada

Vol. 13 No. 2 Juni 2021

Madrasah homepage: http://ejournal.uin-malang.ac.id/index.php/Madrasah/index 
Mata Pelajaran TIK. Jurnal Petik, 6(1), 18-26. https:/ / doi.org/10.31980/jpetik.v6i1.729

Mariyaningsih, N., \& Hidayati, M. (2018). Bukan Kelas Biasa: Teori dan Praktik Berbagai Model dan Metode Pembelajaran Menerapkan Inovasi Pembelajaran di Kelas-Kelas Inspiratif. Kekata Publisher.

Mayasari, T., Kadarohman, A., Rusdiana, D., \& Kaniawati, I. (2016). Apakah Model Pembelajaran Problem Based Learning dan Project Based Learning Mampu Melatihkan Keterampilan Abad 21? Jurnal Pendidikan Fisika Dan Keilmuan (JPFK), 2(1), 48-55. https://doi.org/10.25273/jpfk.v2i1.24

Melinda, V. A., Sambung, D., Ningrum, D. E. A. F., Erfantinni, I. H., \& Febriani, R. O. (2018). Pengembangan Multimedia Pembelajaran Interaktif Materi Pokok Sistem Tata Surya untuk Siswa Kelas VI SD. Madrasah: Jurnal Pendidikan Dan Pembelajaran Dasar, 11(1), 40-45. https:/ / doi.org/10.18860/madrasah.v11i1.6113

Menteri Pendidikan dan Kebudayaan Republik Indonesia. (2016). Standar Proses Pendidikan dasar dan Menengah, Peraturan Menteri Pendidikan dan Kebudayaan Republik Indonesia Nomor 22 Tahun 2016.

Menteri Pendidikan dan Kebudayaan Republik Indonesia. (2020). Pelaksanaan Kebijakan Pendidikan dalam Masa Darurat Penyebaran Coronaviru s Disease (Covid- 1 9), Surat Edaran Menteri Pendidikan dan Kebudayaan Republik Indonesia Nomor 4.

Munir. (2017). Pembelajaran Digital. Alfabeta.

Ningsih, S., Kuntarto, E., \& Kurniawan, A. (2020). Problematika Guru dalam Menggunakan Teknologi Informasi dan Komunikasi (TIK) dan Implikasinya di Sekolah Dasar. JURNAL PAJAR (Pendidikan Dan Pengajaran), 4. https://doi.org/10.33578/pjr.v4i3.7964

Noverdika, Y. (2021). Pengaruh Penggunaan Multimedia Interaktif Model Tutorial dalam Pembelajaran Teknologi Informasi dan Komunikasi Terhadap Hasil Belajar Siswa Kelas VIII SMPN 17 Padang. Jurnal Literasiologi, 5(1), Article 1. https:/ / doi.org/10.47783/literasiologi.v5i1.181

Nugroho, A. (2019). HOTS (Kemampuan Berpikir Tingkat tinggi: Konsep, Pembelajaran, Penilaian, dan Soal-soal) (Cet. Ke-2). Gramedia Widiasarana Indonesia.

Prastowo, A. (2019). Analisis Pembelajaran Tematik terpadu. Kencana Prenada Media Group.

Prayoga, G. S., Sudarma, K., \& Tegeh, I. M. (2016). Pengembangan Multimedia Interaktif Model Tutorial pada Mata Pelajaran PKN Kelas VIII Semester Genap di SMP Negeri 6 Singaraja Tahun Pelajaran 2015/2016. Jurnal Edutech Undiksha, 4(2), Article 2. https://doi.org/10.23887/jeu.v4i2.7633

Purwowidodo, A. (2018). Pengembangan Disain Model Pembelajaran Mobile Learning Berbasis Aplikasi Lectora Inspire sebagai Mindtools pada Proses Pembelajaran Teknologi Pembelajaran. Ta'allum: Jurnal Pendidikan Islam, 6(1), 105-120. https:/ / doi.org/10.21274/taalum.2018.6.1.105-120

Putra, G. T. S., Kesiman, M. W. A., \& Darmawiguna, I. G. M. (2013). Pengembangan Media Pembelajaran Dreamweaver Model Tutorial Pada Mata Pelajaran Mengelola Isi Halaman Web Untuk Siswa Kelas XI Program Keahlian Multimedia Di SMK Negeri 3 Singaraja | Putra | Jurnal Nasional Pendidikan Teknik Informatika: JANAPATI. JANAPATI: Jurnal Nasional Pendidikan Teknik Informatika, 2(2). http:/ / dx.doi.org/10.23887/janapati.v2i2.9782

Vol. 13 No. 2 Juni 2021

Madrasah homepage: http://ejournal.uin-malang.ac.id/index.php/Madrasah/index 


\section{MADRASAH}

Jurnal Pendidikan dan Pembelajaran Dasar

p ISSN: 1979-5599 | e ISSN: 2502-194X

P a g e

Rafianti, I., Setiani, Y., \& Yandari, I. A. V. (2018). Pengembangan Bahan Ajar Interaktif Tutorial dalam Pembelajaran Matematika Siswa SMP. JPPM (Jurnal Penelitian Dan Pembelajaran Matematika), 11(2), Article 2. https:/ / doi.org/10.30870/jppm.v11i2.3759

Rahim, F. R., Suherman, D. S., \& Murtiani. (2019). Analisis Kompetensi Guru dalam Mempersiapkan Media Pembelajaran Berbasis Teknologi Informasi Era Revolusi Industri 4.0. Jurnal Eksakta Pendidikan (JEP), 3(2). https:/ / doi.org/10.24036/jep.v1i2.50

Ramlee, N., Rosli, M. S., \& Saleh, N. S. (2019). Mathematical HOTS Cultivation Via Online Learning Environment and 5E Inquiry Model: Cognitive Impact and The Learning Activities. International Journal of Emerging Technologies in Learning (IJET), 14(24), 140-151.

Rigianti, H. A. (2020). Kendala Pembelajaran Daring Guru Sekolah Dasar di Banjarnegara. Elementary School: Jurnal Pendidikan Dan Pembelajaran Ke-SD-An, 7(2). https:/ / doi.org/10.31316/esjurnal.v7i2.768

Rusman. (2018). Belajar dan Pembelajaran Berbasis Komputer Mengembangkan Profesionalisme Guru Abad 21 (Cet. Ke-3). Alfabeta.

Rusman. (2018). Belajar dan Pembelajaran Berorientasi Standar Proses Pendidikan (Cet. Ke2). Prenadamedia Group.

Sadikin, A., \& Hamidah, A. (2020). Pembelajaran Daring di Tengah Wabah Covid-19. BIODIK: Jurnal Ilmiah Pendidikan Biologi, Vol. 6(No. 2).

Sembiring, E. B., Wahyuni, D., \& Anurogo, W. (2018). Multimedia Interaktif Pengenalan Hewan dan Tumbuhan Langka Menggunakan Model Tutorial. Journal Of Digital Education, Communication, And Arts (DECA), 1(2), 103-112. https:/ / doi.org/10.30871/deca.v1i2.839

Setyawan, B., Rufii, Nf., \& Fatirul, Ach. N. (2019). Augmented Reality Dalam Pembelajaran Ipa Bagi Siswa Sd. Kwangsan: Jurnal Teknologi Pendidikan, 7(1), 7890. https:/ / doi.org/10.31800/jtp.kw.v7n1.p78--90

Sewell, J. P., Frith, K., \& Colvin, M. (2010). Online Assessment Strategies: A Primer. MERLOT Journal of Online Learning and Teaching, 6(1). /paper/OnlineAssessment-Strategies\%3A-A-Primer-Sewell-

Frith/d615080bc198a836023b8fe0f214fc86facd5a9a

Smaldino, S. E., Lowther, D. L., \& Russel, J. D. (2014). Instructional Technology E Media for Learning Teknologi Pembelajaran dan Media untuk Belajar Edisi Kesembilan Diterj. Oleh Arif Rahman (Ke-3). Kencana Prenada Media Group.

Sobarna, E., \& Darmawan, D. (2014). Efektifitas Penggunaan Multimedia Interaktif (MMI) Model Tutorial terhadap Motivasi serta Hasil Belajar Peserta Didik pada Materi Pelajaran Ilmu Pengetahuan Alam Pokok Bahasan Sistem Pernapasan Manusia. EDUTECH: Jurnal Educational Technology, 13(3), 386-399. https:/ / doi.org/10.17509/edutech.v13i3.3092

Sukardi, S., \& Rozi, F. (2019). Pengaruh Model Pembelajaran Online dilengkapi dengan Tutorial terhadap Hasil Belajar. JIPI (Jurnal Ilmiah Penelitian Dan Pembelajaran Informatika), 4(2), 97. https:/ / doi.org/10.29100/jipi.v4i2.1066

Vol. 13 No. 2 Juni 2021

Madrasah homepage: http://ejournal.uin-malang.ac.id/index.php/Madrasah/index 
Sumantri, U. (2019). Penggunaan Video Tutorial dalam Upaya Meningkatkan Prestasi Belajar TIK pada Siswa Kelas XII.IPS-1. Jurnal MetaedukasI, 1(2), Article 2. http:/ /jurnal.unsil.ac.id/index.php/metaedukasi/article/view/1208

Susanto, A. (2019). Teori Belajar dan Pembelajaran di Sekolah Dasar (Ke-2). Kencana Prenada Media Group.

Sutarman, A. (2016). Pemanfaatan Pembelajaran Berbasis Komputer Model CD Interaktif Tutorial untuk Meningkatkan Hasil Belajar. Jurnal Penelitian dan Pembelajaran IPA, 2(1), 81-98. https:/ / doi.org/10.30870/jppi.v2i1.739

Uma, A. (2012). Penggunaan Multimedia Interaktif Guna Menciptakan Pembelajaran yang Inovatif di Sekolah. PERSPEKTIF, 1(1), Article 1. https://doi.org/10.31289/perspektif.v1i1.78

Wahyuningsih, E., \& Mustadi, A. (2016). Pengembangan Multimedia Lectora Pembelajaran Tematik-Integratif untuk Peningkatan Nilai Karakter Siswa Kelas IV Sekolah Dasar. Jurnal Pendidikan Karakter, Tahun VI(1), Article 1. https:/ / doi.org/10.21831/jpk.v0i1.10729

Wardani, S. K., Setyosari, P., \& Husna, A. (2019). Pengembangan Multimedia Tutorial Mata Pelajaran IPA Pokok Bahasan Sistem Tata Surya Kelas VII MTs Raudlatul Ulum Karangploso. Jurnal Kajian Teknologi Pendidikan, 2(1), 23-29. https:/ / doi.org/10.17977/um038v2i12019p023

Yaswinda, Y., Nilawati, E., \& Hidayati, A. (2019). Pengembangan Media Video Tutorial Pembelajaran Sains Berbasis Multisensori Ekologi untuk Meningkatkan Kogntif Anak Taman Kanak-Kanak Kelompok A. Jurnal Audi: Jurnal Ilmiah Kajian Ilmu Anak Dan Media Informasi PAUD, 4(2), 100-109. https:/ / doi.org/10.33061/jai.v4i2.3326

Zulkipli. (2015). Pengembangan Modul Sistem Keamanan Jaringan Program Studi Teknik Komputer dan Jaringan di SMKN 1 Kediri Lombok Barat. In Prosiding Seminar Nasional Teknologi Pendidikan. Program Studi Teknologi Pendidikan Universitas Negeri Malang. 